J. Product. \& Dev., 18(2):155 - 173 (2013)

\title{
RESPONSE OF SOME BARLEY CULTIVARS TO SOWING DATE AND SEEDING RATE UNDER SPRINKLER IRRIGATION SYSTEM IN SANDY SOILS
}

\author{
Abd El-Rahman E. A. Omar \\ Agron. Department, Faculty Agriculture, Zagazig University, Egypt.
}

\begin{abstract}
The present study was conducted in the Experimental Farm, ElKhattara region, Faculty of Agriculture, Zagazig University, Sharkia Governorate, Egypt during 2009/2010 and 2010/2011 seasons. The study aimed to investigate the response of three barley cultivars (Giza 123, Giza 132 and Giza 2000) to two sowing dates (Nov. 20 th and Dec. 20 $0^{\text {th }}$ ) and three seeding rates $(30,45$ and $60 \mathrm{~kg} / \mathrm{fad})$ under sprinkler irrigation in sandy soils.
\end{abstract}

The obtained results from this study clearly indicate that the one month delay in sowing to Dec. $20^{\text {th }}$, adversely affected barley plant growth and development as were expressed in plant height and tillering which were reduced. The development of late sown plants indicated a significant decrease in tiller productivity as was express in a significant decrease in the number of spikes $/ \mathrm{m}^{2}$ and as well as in spike development which was expressed in a significant decrease in spike length, number of grains/spike, 1000-grain weight and finally in grain weight/spike. All these adverse effects were finally reflected in the grain, straw and biological yields/fad. Barley cultivars varied significantly in tallness, tillering, spike development and finally grain yield which was always in favor of Giza 132 as it recorded the highest averages of number of spikes $/ \mathrm{m}^{2}$, grain yield/fad and harvest index. While Giza 2000 surpassed the other two cultivars in plant height, grain weight/spike, 1000-grain weight and straw and biological yields/fad. Seeding rate gave a clear and consistent significant effect on all growth and yield attributes. Increasing seeding rate from 30 to 45 and $60 \mathrm{~kg} / \mathrm{fad}$ caused a significant decrease in spike length, number of grains/spike, grain weight/spike and 1000-grain weight, but the grain yield was however increased due to the increase of the number of spikes $/ \mathrm{m}^{2}$. The detected significant interactions showed varietal response to date of sowing but the main effects of either seeding rate or sowing date recommended early sowing in Nov. $20^{\text {th }}$ and the use of the highest seeding rate $(60 \mathrm{~kg} / \mathrm{fad})$ and as well use of Giza $132 \mathrm{in}$ order to maximize the barley grain yield.

Key words: Barley cultivars, sowing date, seeding rate, sandy soils, yield and its attributes. 


\section{INTRODUCTION}

Barley (Hordeum vulgare, L.) is widely grown in the rainfed and irrigated areas of the arid and semi-arid Mediterranean regions where water and nitrogen are the main limiting factors affecting agriculture production (Mohammad et al., 1999). It ranks the fourth after wheat, rice and maize in the world's cereal production (FAO, 2004). In Egypt, most of barley production areas are located where the adverse condition exists such as moisture and salinity stress as well as poor and low fertility in newly reclaimed lands. Increasing productivity of barley could be achieved through adopting the agronomic practices such as using high yielding varieties and the other culture practices of which sowing date and seeding rate.

Proper sowing date of winter wheat and barley are likely to offer the crop plants the best seasonal thermoperiod and as well as suitable day length for flowering (Musick and Dusek, 1980 and Razzaque and Rafiquzzaman, 2006). On the other hand, late sowing of wheat and barley might expose the crop plants to higher temperature after and during heading, resulting in reduced number of spikes per square meter and number of grains/spike (Randhawa et al., 1977). Late sowing also is always accompanied with late seeding emergence due to low day and night temperatures. Salem et al. (2000) found that delaying sowing date from $15^{\text {th }}$ November to $15^{\text {th }}$ December caused significant decrease in number of spikes/ $\mathrm{m}^{2}$, number of grains/spike, grain weight/spike, 1000-grain weight, grain and straw yields/fad under upper Egypt conditions. Many workers reported that early sowing of barley significantly increased yield and its attributes compared with late sowing (El-Sayed et al., 1998; Samarah and Al-Issa, 2006; Alam et al., 2007 and Rashid et al., 2010). Megahed et al. (2002) obtained the highest averages from grain, straw and biological yields with sowing barley on $20^{\text {th }}$ November followed by $5^{\text {th }}$ November and $5^{\text {th }}$ December under sandy soil condition in Ismailia Governorate. Also, El-Moselhy (2004) reported that delaying sowing date up to January $1^{\text {st }}$ decreased grain yield as the average of two seasons by about $19 \%$ as compared with sowing date December $15^{\text {th }}$ and about $34 \%$ when sowing date delayed up to January $15^{\text {th }}$. In Bangladesh, Alam et al.(2005) found that delaying sowing date after 17 November decreased dry matter accumulation and grain yield. On the other direction, Rashid et al.(2010) found that sowing barley on mid-October produced the highest grain yield compared with sowing on mid-November under Pakistan conditions.

Several investigators reported that barley cultivars showed significant differences in yield and yield attributes due to differences in their genetic background (El-Bawab et al., 2003; Abd El-Hameed and Ash-Shormillesy, 
2005; Razzaque and Rafiquzzaman, 2006; Gaballah and Mowafy, 2007; Ash-Shormillesy et al., 2008; El-Banna et al., 2011; Soleymani et al., 2011 and Ramadhan, 2013).

Optimum plant density may greatly vary between areas according to climatic conditions, soils, sowing times and varieties (Sharifi and Raei, 2011). Increasing seeding rate caused significant increase in plant height, number of spikes/unit area as well as grain and straw yields/unit area, while number of grains/spike, spike length and 1000- grain weight were decreased (El-Afandy, 1999 and Munir, 2002). Also, Lafond et al. (1996) indicated that increasing seeding rate from 27 to $161 \mathrm{~kg}$ seed/ha tended to increase the grain yield and its components. Moreover, Salem et al. (2000) found that increasing seeding rate from 35 to $65 \mathrm{~kg}$ seeds/fad caused significant increase in plant height, number of spikes $/ \mathrm{m}^{2}$, grain and straw yields/fad while, spike length, number of grains/spike, grain weight/spike as well as 1000-grain weight were decreased. The highest grain yield of barley could be obtained by increasing seeding density up to $350 \mathrm{seeds} / \mathrm{m}^{2}$ (Soleymani et al., 2011), 450 seeds $/ \mathrm{m}^{2}$ (Noworolnik, 2010) and 500 seeds $/ \mathrm{m}^{2}$ (Sharifi and Raei, 2011). However, Donavon et al. (2011) found that increasing seeding rate from 200 to 400 seeds $/ \mathrm{m}^{2}$ had no significant effect on grain yield of malting barley cultivars grown under Canadian conditions. Furthermore, Ramadhan (2013) indicated that increasing seeding rate from 100 to 140 $\mathrm{kg} / \mathrm{ha}$ caused significant increase in number of tillers $/ \mathrm{m}^{2}$, plant height, number of spikes $/ \mathrm{m}^{2}$, grain and biological yields.

Therefore, this study aimed to investigate the effect of sowing date, cultivars and seeding rate on yield and its attributes of barley under newly reclaimed sandy soil conditions using sprinkler irrigation system.

\section{MATERIALS AND METHODS}

Two field experiments were carried out in the Agricultural Research Station, Faculty of Agriculture, Zagazig University at El-Khattara region, Sharkia Governorate, Egypt during the two successive winter seasons $2009 / 2010$ and 2010/2011. The study aimed to investigate the response of barley cultivars to sowing dates and seeding rates under sprinkler irrigation system in newly reclaimed sandy soils. The soil of the experimental site was sandy in texture, where it had a particle size distribution of 92.52, 4.28 and $3.20 \%$ for sand, silt and clay, respectively (averages of the two seasons for the upper $30 \mathrm{~cm}$ soil depth). The soil had an average $\mathrm{pH}$ of 8.12 and organic matter content of $0.09 \%$. The average available $\mathrm{N}, \mathrm{P}$ and $\mathrm{K}$ contents were $11.5,4.1$ and $63 \mathrm{ppm}$, respectively. A split- split plot design with three replicates was used. The main plots were assigned to two sowing dates i.e. 
$20^{\text {th }}$ Nov. and $20^{\text {th }}$ Dec. The sub-plots were occupied with three barley cultivars i.e. Giza 123, Giza 132 and Giza 2000, whereas the sub-sub plots were devoted to three seeding rates i.e. 30,45 and $60 \mathrm{~kg}$ grains/fad. The sub-sub plot area was $12 \mathrm{~m}^{2}(3 \times 4 \mathrm{~m})$ included 20 rows each of $4 \mathrm{~m}$ length and $15 \mathrm{~cm}$ apart. In both seasons, the preceding crop was sorghum. Phosphorus and potassium fertilizers were added during seed bed preparation at levels of $31 \mathrm{~kg} \mathrm{P}_{2} \mathrm{O}_{5} / \mathrm{fad}$ in the form of ordinary calcium superphosphate $\left(15.5 \% \mathrm{P}_{2} \mathrm{O}_{5}\right)$ and $48 \mathrm{~kg} \mathrm{~K}_{2} \mathrm{O} / \mathrm{fad}$ as potassium sulphate $\left(48 \% \mathrm{~K}_{2} \mathrm{O}\right)$. Nitrogen fertilizer was applied as ammonium sulphate $(20.5 \%$ $\mathrm{N})$ at a level of $80 \mathrm{~kg} \mathrm{~N} / \mathrm{fad}$ in five equal doses, the first at 15 days from sowing, and the rest every 15days. Sprinkler irrigation was followed. The other agronomic practices were carried out as recommended. In each subsub plots, one meter length was defined at random in each of the three central rows $\left(0.45 \mathrm{~m}^{2}\right)$ at seedling stage. Number of tillers/ $\mathrm{m}^{2}$ was counted (at 60 days from sowing) and number of spikes $/ \mathrm{m}^{2}$ (at harvest). In the same time, at harvest, ten guarded plants were randomly selected from each plot for recording the following traits: Plant height $(\mathrm{cm})$, spike length $(\mathrm{cm})$, number of grains/spike, grain weight/spike $(\mathrm{g})$. Also, an area of $3 \mathrm{~m}^{2}$ was harvested from each plot to determine the following traits: Thousand grain weight $(\mathrm{g})$, grain yield $(\mathrm{t} / \mathrm{fad})$, straw yield $(\mathrm{t} / \mathrm{fad})$, biological (grain $+\mathrm{straw})$ yield $(\mathrm{t} / \mathrm{fad})$ and harvest index $(\mathrm{HI})$.

Data were analyzed according to Snedecor and Cochran (1981). For comparison between means, Duncan's multiple range test was used (Duncan, 1955). The error mean squares of split-split plot design were homogenous (Bartlett's test), therefore, the combined analysis was calculated for all the studied characters in both seasons. Statistical analysis was performed by using analysis of variance technique of (MSTST-C 1991) computer software package. In interaction Tables, capital and small letters were used to compare rows and columns means, respectively. The response of grain yield (combined analysis) to seeding rate was calculated using orthogonal polynomial tables according to Snedecor and Cochran (1981) and the following equation was used:

$$
\hat{\mathrm{Y}}=\mathrm{a}+\mathrm{bx}-\mathrm{cx}^{2}
$$

Where $\hat{Y}$ is the yield (dependent variable), $\mathrm{x}$ is the seeding rate as independent variable, $\mathrm{a}$ is the intercept, and $\mathrm{b}$ and $\mathrm{c}$ are the linear and quadratic regression coefficients, $\mathrm{X}$ max (predicted maximum seeding rate) $=\mathrm{b} / 2 \mathrm{c}(\mathrm{u}), \mathrm{Y} \max ($ predicted maximum grain yield $)=\mathrm{a}+\mathrm{b}^{2} / 4 \mathrm{c}$, where $\mathrm{u}=$ The interval between rates of seeding. 


\section{RESULTS AND DISCUSSION}

\section{Plant height and tillering $/ \mathrm{m}^{2}$}

Results in Table 1 show the effect of sowing dates and seeding rates on plant height and number of tillers and spikes $/ \mathrm{m}^{2}$ of the three barley cultivars and their interactions in the two seasons and their combined.

Regarding the effect of sowing date, it was quite evident that delaying sowing to Dec. $20^{\text {th }}$ was followed by a significant decrease in each of plant height, number of tillers $/ \mathrm{m}^{2}$ and number of spikes $/ \mathrm{m}^{2}$ compared with early sowing on Nov. $20^{\text {th }}$. This effect was observed in the two seasons and their combined. These results clearly indicate that the climatic conditions were not in a favor of barley plants when sowing was delayed to 20 December. Probably the lower temperature and the critical day length were among the most effecting factors governing the growth of late sown plants. In Egypt, Dec. $23^{\text {rd }}$ is the day of the shortest photoperiod where thereafter days become longer i.e. day hours tend to increase and hence force the long day plants of which barley belong to commit reproduction earlier than those sown on 20 November. The latters had chance of one month to grow in length and as well as in branching than the formers. Therefore, late sowing produced shorter plants with lower number of tillers than early sowing. Late sown plants as well might have had not received their vernalization requirements and hence a larger number of tillers failed to bear spikes as expressed here in a significant decrease in number of spikes $/ \mathrm{m}^{2}$ due to late sowing. These results agreed with those obtained by Salem et al. (2000), ElMoselhy et al. (2004), Alam et al. (2007) and Rashid et al. (2010) as they observed significant decreases in plant height and tillering capacity with delaying sowing date while, Soleymani et al. (2011) reported that sowing date had no significant effect on plant height and number of tillers/plant.

Regarding varietals differences Giza 2000 had the longest plants with at par average with Giza 132 where the shortest plants were produced by Giza 123 in the first season. These differences did not reach the level of significance in the second season. However, the combined analysis ascertained the superiority of Giza 2000 in plant height but the other two cultivars had at par lower plant height average. The trend of cultivars in tillering was different where the highest numbers of tillers or spikes $/ \mathrm{m}^{2}$ were recorded by Giza 132 followed by Giza 2000 and then Giza 123 which recorded the lowest average. These data indicate that the tallness of Giza 2000 in height was to a certain extent on the expense of its tillering. This partially could be attributed to the apical dominance where plant elongation was reported to hinder further tillering in winter cereals as reported by Friend et al. (1962). This phenomenon was clearly expressed by Giza 2000 where it had the longest plants but not the highest number of tillers. The 
performance of Giza 123 regarding elongation and tillering was worst among the three tested barley cultivars as it had the lowest number of tillers and spikes $/ \mathrm{m}^{2}$ and as well as the shortest plants though the differences with Giza 132 did not reach the level of significance. These results are in harmony with those obtained by Abd El-Hameed and Ash-Shormillesy (2005), Gaballah and Mowafy (2007), El-Banna et al.(2011) and Ramadhan (2013).

Regarding the effect of seeding rate, each increase in this rate was followed by a significant increase in plant height, number of tillers and hence spikes $/ \mathrm{m}^{2}$ in both seasons and their combined (Table 1). The increase in plant height with the increase of seeding rate could be attributed to the elongating effect always caused by dense planting where the proportion of invisible radiation is increased among dense sown plants. This radiation was reported by Pessarakli, (2001) to have an elongating effect on growing plants. However, the increase in number of tillers or spikes $/ \mathrm{m}^{2}$, caused by the increase of seeding rate, could be attributed to the increase in number of plants $/ \mathrm{m}^{2}$. But this increase was not proportional with the increase of seeding rate due to more plant competition for growth resources, particularly plant nutrients. Mutual shading among the dense sown barley plants which in turn decrease the proportion of photosynthetically active ration (PAR) cannot be neglected in this respect as dense sown plants might have had suffered from shortage in the amount of assimilates available for their development. Therefore, the elongation effect of the invisible radiation was a reflection to a hormonal action whereas the decrease of tillering and hence the number of tillers and spikes/plant was a nutritional action though both were interacting resulting in a significant decrease in the number of tillers and hence spikes $/ \mathrm{m}^{2}$ but due to the increase of plant population of the dense sown plants, the number of tillers and spikes $/ \mathrm{m}^{2}$ was increased. These results agreed with the findings of Salem et al., 2000, Soleymani et al., 2011 and Ramadahn (2013) who reported that plant height, number of tillers $/ \mathrm{m}^{2}$ and number of spikes $/ \mathrm{m}^{2}$ were increased with increasing seeding rate.

According to the combined analysis, significant interaction between barley cultivars and seeding rates on each of plant height, number of tillers $/ \mathrm{m}^{2}$ and number of spikes $/ \mathrm{m}^{2}$ are presented in Tables 1-a, 1-b and 1-c, in respective. It is evident from Table 1-a that plant height of Giza 132 and Giza 2000 cultivars responded to the highest seeding rate $(60 \mathrm{~kg}$ seeds/fad) whereas, Giza 123 responded to only $45 \mathrm{~kg}$ seeds/fad. It seems evident that Giza 2000 cultivar was more responsive to the increase of seeding rate than the other two cultivars as expressed in higher regression coefficient. This 
Table 1-a. Plant height $(\mathrm{cm})$ as affected by the interaction between cultivars and seeding rates (combined analysis of two seasons)

\begin{tabular}{|c|c|c|c|c|}
\hline $\begin{array}{ll}\text { Cultivars } & \text { Seeding rates } \\
\end{array}$ & 30 & 45 & 60 & $\begin{array}{l}\text { Regression } \\
\text { coefficient }\end{array}$ \\
\hline & B & A & A & \\
\hline Giza 123 & $\begin{array}{l}81.01 \mathrm{~b} \\
\mathrm{C}\end{array}$ & $\begin{array}{c}85.09 \mathrm{a} \\
\mathrm{B}\end{array}$ & $\begin{array}{c}86.04 \mathrm{c} \\
\mathrm{A}\end{array}$ & 2.52 \\
\hline Giza 132 & $\begin{array}{l}82.89 \mathrm{ab} \\
\mathrm{C}\end{array}$ & $\begin{array}{c}86.15 \mathrm{a} \\
\mathrm{B}\end{array}$ & $\begin{array}{c}88.58 b \\
\text { A }\end{array}$ & 2.85 \\
\hline Giza 2000 & $84.00 \mathrm{a}$ & $86.41 \mathrm{a}$ & $93.03 \mathrm{a}$ & 4.52 \\
\hline
\end{tabular}

Capital and small letters were used to compare means of rows and columns, respectively

Table 1-b. Number of tillers $/ \mathrm{m}^{2}$ as affected by the interaction between cultivars and seeding rates (combined analysis of two seasons)

\begin{tabular}{|c|c|c|c|c|}
\hline $\begin{array}{ll} & \text { Seeding rates } \\
\text { Cultivars } & \end{array}$ & 30 & 45 & 60 & $\begin{array}{l}\text { Regression } \\
\text { coefficient }\end{array}$ \\
\hline & $\mathrm{C}$ & B & A & \\
\hline Giza 123 & $\begin{array}{c}345.82 \mathrm{c} \\
\mathrm{C}\end{array}$ & $\begin{array}{c}451.62 b \\
B\end{array}$ & $\begin{array}{c}516.25 \mathrm{c} \\
\mathrm{A}\end{array}$ & 85.22 \\
\hline Giza 132 & $\begin{array}{c}378.15 \mathrm{a} \\
\mathrm{C}\end{array}$ & $\begin{array}{c}489.67 \mathrm{a} \\
\mathrm{B}\end{array}$ & $\begin{array}{c}561.75 a \\
A\end{array}$ & 91.80 \\
\hline Giza 2000 & $358.97 \mathrm{~b}$ & $456.17 \mathrm{~b}$ & $532.94 b$ & 86.99 \\
\hline
\end{tabular}

Table 1-c. Number of spikes $/ \mathrm{m}^{2}$ as affected by the interaction between cultivars and seeding rates (combined analysis of two seasons)

\begin{tabular}{|c|c|c|c|c|}
\hline $\begin{array}{ll}\text { Cultivars } & \text { Seeding rates } \\
\end{array}$ & 30 & 45 & 60 & $\begin{array}{l}\text { Regression } \\
\text { coefficient }\end{array}$ \\
\hline & $\bar{C}$ & B & $\overline{\mathrm{A}}$ & \\
\hline Giza 123 & $\begin{array}{c}208.42 c \\
C\end{array}$ & $\begin{array}{c}278.92 \mathrm{c} \\
\mathrm{B}\end{array}$ & $\begin{array}{c}333.17 b \\
\text { A }\end{array}$ & 62.38 \\
\hline Giza 132 & $\begin{array}{l}241.50 \mathrm{a} \\
\mathrm{C}\end{array}$ & $\begin{array}{c}326.33 a \\
\text { B }\end{array}$ & $\begin{array}{c}363.58 \mathrm{a} \\
\mathrm{A}\end{array}$ & 61.04 \\
\hline Giza 2000 & $218.25 b$ & $292.08 b$ & $338.25 b$ & 60.00 \\
\hline
\end{tabular}

Capital and small letters were used to compare means of rows and columns, respectively

differential varietals response resulted in the highest plant height average recorded by this cultivar as the highest seeding rate. It is evident from Table 1-b that each increase in seeding rate resulted in a significant increase in the number of tillers $/ \mathrm{m}^{2}$ in the three barley cultivars but, also with different magnitudes as expressed the regression coefficient. Giza 132 showed the highest response to the increase of seeding rate compared with the other two cultivars which had an almost similar regression coefficient. This again 
expressed the high tillering capacity of this cultivar where it recorded the highest number of tillers $/ \mathrm{m}^{2}$ at the highest seeding rate. Finally, Table 1-c showed that the three barley cultivars responded to each increase in seeding rate but also with different magnitudes which varied but not as much as that of the number of tillers $/ \mathrm{m}^{2}$. These results indicate that the productivity of tillers varied among the three barley cultivars as this was expressed in differences in percentage of spikes $/ \mathrm{m}^{2}$ to tillers $/ \mathrm{m}^{2}$ at the highest seeding rate which amounted to $64.6,64.7$ and $63.5 \%$ for the three barley cultivars in respective order. This productivity was more varied at the lowest seeding rate being $60.3,63.8$ and $60.8 \%$ for the three barley cultivars in respective order. It seems evident that the effect of seeding rate on the number of tillers $/ \mathrm{m}^{2}$ was more clear at the lowest than at the highest seeding rate.

\section{Spike length and grain weight/spike attributes}

It is quite evident from Table 2 that delaying sowing to Dec. $20^{\text {th }}$ instead of Nov. $20^{\text {th }}$, resulted in a significant decrease in spike length, grains number/ spike, 1000-grain weight and hence the grain weight/spike. These results are rather expected as delaying sowing produced shorter plants with lower number of tillers and spikes $/ \mathrm{m}^{2}$ (Table 1), indicating retarded growth and in turn lower amounts of photosynthesis available for grain set and grain filling as compared with early sowing in November. Similar results were obtained by El-Sayed et al. (1998), Alam et al. (2005), Samarah and Al-Issa (2006) and Rashid et al. (2010). Also, Salem et al. (2000) reported that delaying sowing date from $15^{\text {th }}$ Nov. to $15^{\text {th }}$ Dec. caused significant decrease in number of grains/spike, 1000-grain weight and grain weight/spike but, spike length was not affected by sowing date.

Regarding varietal differences in grain weight/spike and its attributes, Giza 123 had the shortest spikes whereas, Giza 132 and Giza 2000 had a par longer spikes in both seasons and their combined (Table 2). However, Giza 2000 had larger number of grains/spike than the other two cultivars in the second season, but the combined analysis indicated the insignificancy of these differences in this trait. Finally, 1000-grain weight judged the superiority of Giza 2000 where it had the heavier weight followed by Giza 132 and then Giza 123 which recorded the lightest 1000-grain weight in both seasons and their combined. Therefore, Giza 2000 recorded the heaviest grain weight/spike followed by Giza 132 and then Giza 123 with significant differences in both seasons and their combined. These results clearly indicate that the grain weight/spike, which was the heaviest by Giza 2000 was not governed by spike length or the number of grains/spike but however governed by the 1000-grain weight. Also, Giza 2000 had recorded 
the second order number of spikes $/ \mathrm{m}^{2}$ after Giza 132 therefore might have had afforded less inter and intra-plant competition than Giza 132 and hence had more enough photosynthates for grain set in the second season as expressed in the number of grains/spike and as well as for grain filling as expressed in 1000grain weight in both seasons and their combined. These results are in a good line with those obtained by El-Bawab et al. (2003), El-Moselhy (2004), Gaballah and Mowafy (2007), Ash-Shormillesy et al. (2008), Soleymani et al. (2011) and Ramadahn (2013).

Regarding the effect of seeding rate on spike length and grain weight/ spike attributes, a consistent significant decrease was observed in each of spike length, number of grains/spike, 1000-grain weight and grain weight/ spike with each increase in seeding rate (Table 2). These results clearly indicate that the increase in the number of tillers or spikes $/ \mathrm{m}^{2}$ was on the expense of grain weight/spike as it was decreased with the increase of seeding rate. In otherworld, barley plants at the highest seeding rate could not manage a safe competition between and within plants which might have had governed the grain weight/spike due to the decrease of grain set and filling as their averages were, also decreased with the increase of seeding rate. Reductions in spike length, number of grains/spike, grain weight/spike and 1000-grain weight have been associated with increasing seeding rate were reported by Salem et al., (2000), Munir, (2002) and Ramadahn (2013).

Regarding the interaction effect, the combined analysis did not detect any significant effect on spike length, number of grains/spike, 1000-grain weight and grain weight/spike (Table 2). These results clearly indicate that spike length and development were governed by the main effect of each factor under study rather than any interacting effect between each two of them.

\section{Grain, straw and biological yields/fad and harvest index:}

As far as, the effect of sowing date on the final barley yields/fad, it is clear from Table 3 that delay of sowing resulted in a significant decrease in each of grain, straw and hence the biological yields /fad as well as harvest index. The retarded growth which was expressed in plant height and tillering (Table 1) and as well in spike length and all of its development attributes (Table 2) caused by delay of sowing was finally resulted in a significant decrease in the grain and straw yields/fad. The decrease of harvest index which was observed in the first season and ascertained by the combined analysis, clearly indicate that late sown plants have had might built more canopy on the expense of grain yield. These results are in harmony with those obtained by El-Sayed et al. (1998), Salem et al. (2000), Megahed et al. (2002), El-Moselhy (2004), Razzaque and Rafiquzzaman (2006), Samarah and Al-Issa (2006), Alam et al. (2007), Rashid et al. 
(2010) and Hessan and Moftha (2012). On the other direction, Soleymani et al. (2011) found that sowing date had no significant effect on straw yield/ha and harvest index.

As far as, varietals differences in grain yield and biological yield/fad, results in Table 3 clearly show the superiority of Giza 132 followed by Giza 2000 and then by Giza 123 with clear significant differences in both seasons and their combined (Table 3). These results are rather expected as Giza 132 recorded the highest number of spikes $/ \mathrm{m}^{2}$ (Table 1) followed by Giza 2000 which had the heavier grain weight/spike (Table 2) indicating that the former yield component governed the trend of both grain and straw and hence that biological yields/fad. It is quite interesting to note down here that Giza 132 recorded also the highest harvest index indicating its superiority in dry matter portioning towards grain filling and hence grain yield/fad. These results are in harmony with those obtained by El-Moselhy (2004), Abd ElHameed and Ash-Shormillesy (2005), Gaballah and Mowafy (2007), ElBanna et al. (2011), Soleymani et al. (2011) and Ramadahn (2013).

Finally, the effect of seeding rate on grain, straw and biological yields/ fad was in favor of the highest seeding rate in both seasons and their combined. Each increase in seeding rate was accompanied by significant increase in grain, straw and biological yields/fad (Table 3). Dense sown plants had larger number of spikes $/ \mathrm{m}^{2}$ which compensated the reduction in the other yield components (number of grains/spike, 1000-grain weight and grain weight/spike and). This may explain the increase in grain yield as the seeding rate increased. The increase in straw yield is mainly due to the increase in number of tillers $/ \mathrm{m}^{2}$ and plant height. Harvest index responded to only the moderate seeding rate $(45 \mathrm{~kg}$ seeds/fad) in the first season and combined analysis while, this response reached the highest seeding rate $(60$ $\mathrm{kg}$ seeds/fad) in the second season. These results confirmed those reported by Salem et al. (2000) and Ramadahn (2013). Many workers revealed the importance of increasing seeding rate to increase the productivity of barley (El-Sayed et al., 1998; Munir, 2002; Noworolnik, 2010 and Sharifi and Raei, 2011).

Regarding the interaction effect on grain, straw and biological yields/ fad, the combined analysis detected significant effects due to the sowing date $\mathrm{x}$ barley cultivars interaction on grain, straw and biological yields/fad as well as harvest index as shown in Tables 3-a, 3-b, 3-c and 3-d in respective order. Harvest index was also affected by the sowing date $\mathrm{x}$ seed rate interaction (Table 3-e). Regarding the effect of sowing date x cultivars interaction, the grain yield/fad was decreased due to delay of sowing in the three barley cultivars but Giza 2000 was the least affected as judged by the percentage reduction which was only $21.0 \%$ in the aforementioned cultivar 
Table 3-a. Grain yield (ton/fad) as affected by the interaction between sowing dates and cultivars (combined analysis of two seasons)

\begin{tabular}{|c|c|c|c|}
\hline $\begin{array}{ll}\text { Sowing dates } & \text { Cultivars } \\
\end{array}$ & Giza 123 & Giza 132 & Giza 2000 \\
\hline $\begin{array}{l}20^{\text {th }} \text { Nov. } \\
20^{\text {th }} \text { Dec. }\end{array}$ & $\begin{array}{c}\mathrm{C} \\
1.385 \mathrm{a} \\
\mathrm{C} \\
1.027 \mathrm{~b}\end{array}$ & $\begin{array}{c}\mathrm{A} \\
1.769 \mathrm{a} \\
\mathrm{A} \\
1.327 \mathrm{~b}\end{array}$ & $\begin{array}{c}\mathrm{B} \\
1.579 \mathrm{a} \\
\mathrm{B} \\
1.248 \mathrm{~b}\end{array}$ \\
\hline
\end{tabular}

Table 3-b. Straw yield (ton/fad) as affected by the interaction between sowing dates and cultivars (combined analysis of two seasons)

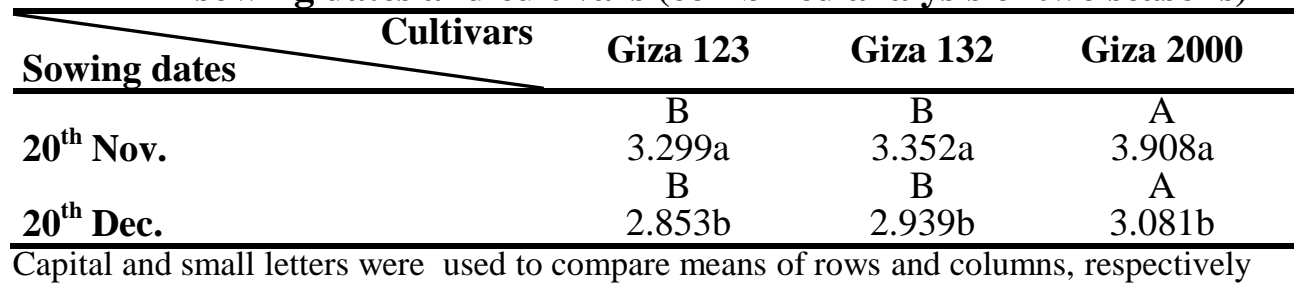

Table 3-c. Biological yield (ton/fad) as affected by the interaction between sowing dates and cultivars (combined analysis of two seasons)

\begin{tabular}{|c|c|c|c|}
\hline $\begin{array}{ll}\text { Sowing dates } & \text { Cultivars } \\
\end{array}$ & Giza 123 & Giza 132 & Giza 2000 \\
\hline $\begin{array}{l}20^{\text {th }} \text { Nov. } \\
20^{\text {th }} \text { Dec. }\end{array}$ & $\begin{array}{c}\mathrm{C} \\
4.684 \mathrm{a} \\
\mathrm{B} \\
3.880 \mathrm{~b}\end{array}$ & $\begin{array}{c}\mathrm{B} \\
5.121 \mathrm{a} \\
\mathrm{A} \\
4.266 \mathrm{~b}\end{array}$ & $\begin{array}{c}\mathrm{A} \\
5.487 \mathrm{a} \\
\mathrm{A} \\
4.329 \mathrm{~b}\end{array}$ \\
\hline
\end{tabular}

Capital and small letters were used to compare means of rows and columns, respectively

Table 3-d. Harvest index (\%) as affected by the interaction between sowing dates and cultivars (combined analysis of two seasons)

\begin{tabular}{lcccc}
\hline Sowing dates & Cultivars & Giza 123 & Giza 132 & Giza 2000 \\
\hline $\mathbf{2 0}^{\text {th }}$ Nov. & $\mathrm{B}$ & $\mathrm{A}$ & $\mathrm{B}$ \\
$\mathbf{2 0}^{\text {th }}$ Dec. & $29.61 \mathrm{a}$ & $34.42 \mathrm{a}$ & $29.03 \mathrm{a}$ \\
\hline
\end{tabular}

Capital and small letters were used to compare means of rows and columns, respectively

Table 3-e. Harvest index (\%) as affected by the interaction between sowing dates and seeding rates (combined analysis of two seasons)

\begin{tabular}{|c|c|c|c|c|}
\hline $\begin{array}{l}\text { Seeding rates } \\
\text { Sowing dates }\end{array}$ & 30 & 45 & 60 & $\begin{array}{l}\text { Regression } \\
\text { coefficient }\end{array}$ \\
\hline $20^{\text {th }}$ Nov. & $\begin{array}{c}\mathrm{B} \\
29.91 \mathrm{a}\end{array}$ & $\begin{array}{c}\mathrm{A} \\
31.47 \mathrm{a}\end{array}$ & $\begin{array}{c}\mathrm{A} \\
31.68 \mathrm{a}\end{array}$ & 0.885 \\
\hline $20^{\text {th }}$ Dec. & $25.44 \mathrm{~b}$ & $30.01 \mathrm{~b}$ & $31.11 \mathrm{a}$ & 2.835 \\
\hline
\end{tabular}

Capital and small letters were used to compare means of rows and columns, respectively 
compared with $25.8 \%$ and $25.0 \%$ for Giza 123 and Giza 132, in respective order (Table 3-a). This sowing date effect was also observed on straw yield/fad, but however, Giza 2000 was the most affected followed by Giza 123 and Giza 132, in respective order (Table 3-b). Finally, the biological yield/fad followed the trend of straw yield/fad where again Giza 2000 was the most affected by delay of sowing followed by Giza 123 and Giza 132 which had par reduction averages (Table 3-c). The harvest index of Giza 2000 , therefore, was not decreased due to delay of sowing, whereas it was decreased by $9.0 \%$ in Giza 132 and $11.4 \%$ in Giza 123 (Table 3-d). These varietal responses to date of sowing reflect their performance during growth and development, which certainly varied and finally was reflected in the grain, straw and biological yields and harvest index at harvest. Judging from the varietal response of grain yield/fad which is main target for growing any cereal crop, Giza 2000 was the least adversely affected by delay of sowing whereas, the other two cultivars are at par from this point of view. Finally, the effect of seeding rate $\mathrm{x}$ sowing date interaction in which affected harvest index clearly indicate that delay of sowing did not reduce the harvest index of dense sown plants whereas it decreased by 14.9 and $4.6 \%$ for the thinnest and moderate seeding rates (Table 3-e). As far as, harvest index is concerned, delay of sowing reflected an almost similar negative effect on both grain and straw yields and hence biological yield/fad when plants were grown under dense sowing.

\section{Grain yield response analysis:}

The barley grain yield/fad responded to the increase of seeding rate up to the highest rate i.e. $60 \mathrm{~kg} / \mathrm{fad}$. This response was attributed to the increase in the number of spikes $/ \mathrm{m}^{2}$ irrespective to decrease of the grain weight/spike when the rate of seeding was increased. The questions, which could be raised from these responses are: what is the possibility of increasing the seeding rate to more $60 \mathrm{~kg} / \mathrm{fad}$ in order to maximize yield. This possibility is certainly governed by the possibility of maximizing the number of spikes/ $\mathrm{m}^{2}$ and as well minimizing the decrease of the grain weight/spike in order finally, to maximize the grain yield/fad. The response equation of grain yield/ fad was calculated from the combined data of the two seasons and was as follows: $\hat{Y}$ grain $/$ fad $=1.136+0.386 x-0.078 x^{2}$. From this equation the predicted maximum grain yield/fad was $1.605 \mathrm{t} / \mathrm{fad}$ which could be obtained if the seeding rate was increased to $66.4 \mathrm{~kg} / \mathrm{fad}$ instead of $60 \mathrm{~kg}$ actually used in this study and did actually produce a grain yield of $1.589 \mathrm{t} /$ fad (Table 3 ). The second question which could be raised herein, what is possibility of maximizing the number of spikes $/ \mathrm{m}^{2}$. Therefore, the response equation was calculated and was as follows: $\hat{Y}$ spikes $/ \mathrm{m}^{2}=222.72+91.64 \mathrm{x}-5.25 \mathrm{x}^{2}$. From this equation a predicted maximum of 360.39 spikes $/ \mathrm{m}^{2}$ could be have been 
obtained if the seeding rate could have been maximized to $75 \mathrm{~kg} / \mathrm{fad}$ instead of the highest one used in this study i.e. $60 \mathrm{~kg} / \mathrm{fad}$ which actually produced 345 spikes $/ \mathrm{m}^{2}$ (Table 1 ). The third question which could then be raised to what extent the grain weight/spike could be sustained against the decrease caused by the increase in seeding rate? The response equation of grain weight/spike was as follows: Ŷgrain wt/spike $=2.007-0.198 \mathrm{x}+0.012 \mathrm{x}^{2}$. This equation indicated that the predicted minimum grain weight/spike $(1.191 \mathrm{~g})$ could not be reached unless seeding rate is increased to $153.8 \mathrm{~kg} / \mathrm{fad}$ i.e. double the seeding rate predicted to maximize the number of spikes $/ \mathrm{m}^{2}$ (75 $\mathrm{kg} / \mathrm{fad}$ ). According to these results attempts devoted to maximize the grain yield/fad through the use of $66.4 \mathrm{~kg}$ seeds/fad will add only $16 \mathrm{~kg}$ grain yield/fad to the maximum grain yield already obtained through the use of 60 $\mathrm{kg} / \mathrm{fad}$ i.e. $1.589 \mathrm{t} / \mathrm{fad}$. The calculation of the response equations of two main yield components i.e. number of spikes $/ \mathrm{m}^{2}$ and grain weight/spike theoretically predicted higher increase in the grain yield/fad due to a higher predicted possible increase in the number of spikes $/ \mathrm{m}^{2}$ without a great decrease to the grain weight/spike as the rate of increase of the former yield component surpassed the rate of decrease in the latter.

Conclusively, this yield analysis ascertained the view that the highest seeding rate used in this study i.e. $60 \mathrm{~kg} / \mathrm{fad}$ was quite enough to maximize the grain yield/fad and therefore is recommended for the three barley cultivars under study as there was no significant varietal response to seeding rate as far as the grain yield/fad is concerned.

\section{REFERENCES}

Abd El-Hameed, I.M. and S.M.A.I. Ash-Shormillesy (2005). Effect of nitrogen and micronutrients fertilizations on yield of some barley cultivars grown under sandy soil conditions. Zagazig J. Agric. Res., 32(5): 1381-1401.

Alam, M.Z.; S.A. Hader and N.K. Paul (2005). Effect of sowing time and nitrogen fertilization on barley (Hordeum vulgare L.). Bangladesh $J$. Bot., 34(1): 27-30.

Alam, M.Z.; S.A. Hader and N.K. Paul (2007). Yield and yield components of barley (Hordeum vulgare L.) in relation to sowing times. Bio-Sci., 15: 139-145.

Ash-Shormillesy, S.M.A.I.; A.M. Helmy and A.E.A. Omar (2008). Effect of sowing methods and nitrogen fertilizer levels on the productivity and nutrients uptake of two new hulless barley cultivars. Egypt. J. Appl. Sci., 23(6A): 345-367. 
Donavon, J.T.; T.K. Turkington; M.J. Edney; G.W. Clayton, R.H. Mckenzie; P.E. Juskiw; G.P. Lafond; C.A. Grant; S. Brandt; K.N. Harker; E.N. Johnson and W.E. May (2011). Seeding rate, nitrogen rate and cultivar effects on barley malting production. Agronomy Journal, 103: 709-716.

Duncan, D.B. (1955). Multiple range and multiple F-test. Biometric, 11: 1-24.

El-Afandy, Kh.T. (1999). Effect of nitrogen levels and seeding rates on yield and yield components of some barley cultivars under saline conditions. J. Agric. Sci., Mansoura Univ., 24(8): 3799-3810.

El-Banna, M.N.; M.A.A. Nassr; M.N. Mohamed and M.A. Boseely (2011). Evaluation of 16 barley genotypes under calcareous soil condition in Egypt. J. Agric. Sci., 3 (1): 105-121.

El-Bawab, A.A.O.; M.A. El-Moselhey and M.A. Megahed (2003). Water and fertilizer requirements for barley in sandy soils. Egypt. J. Appl. Sci., 18 (7): 125-133.

El-Moselhy, M. A. (2004). Study of late sowing dates of barley for maximizing the utilization of irrigated lands after late summer crops. $J$. Agric. Sci., Mansoura Univ., 29(10): 5529-5537

El-Sayed, A.A.; A.A. Mansour; M.A. El-Moselhy and A.M. Orabi (1998). Effect of sowing date and seeding rate on barley production in the new valley. J. Agric. Sci., Mansoura Univ., 23(2): 633-641.

FAO, (2004). http://apps.fao.org/faostat/default.jsp, accessed February 2004.

Friend, D.J.C.; V.A. Helson and J.A. Fisher (1962). Leaf growth in marquis wheat, as regulated by temperature, light intensity and day length. Can. J. Bot., 40: 1299-1311.

Gaballah, A.B. and S.A. Mowafy (2007). Response of some barley cultivars to organic manuring and foliar application of the micronutrients mixture fertilan 10 under new reclaimed sandy soil conditions. J. Product. \& Dev., 12 (1): 1-12.

Hessan, T.F. and A.J. Moftha (2012). Response of yield and its components of some barley varieties to sowing date under El-Baida, Libya conditions. J. Plant Production, Mansoura Univ., 3 (5): 907-912.

Lafond, G.P.; D. Domitruk; K.L. Bailey and D.A. Derksen (1996). Effect of row spacing, seeding rate and seed placed phosphorus on wheat and barley in the Canadian periries. Better-Crop with Plant Food, 80 (4): 20-22.

Megahed, M.A.; M.A. El-Moselhy and A.A. El-Sayed (2002). Effect of sowing dates and N,P fertilization on vegetative growth and yield of two hull-less barley genotypes in sandy soils. Egypt. J. Appl. Sci., 17(11): 162-176.

Mohammad, M.J.; S. Zuraiqi; W. Quameh and I. Papadopoulud (1999). Yield response and nitrogen utilization efficiency by drip-irrigated potato. Nut. Cycling in Agro-ecosystems., 54, 243-249. 
MSTAT-C, (1991). A Microcomputer Program for the Design, Management and Analysis of Agronomic Research Experiment. MSTAT Development Team, Michigan State University.

Munir, A.T. (2002). Influence of varying seeding rates and nitrogen levels on yield and yield components of barley (Hordeum vulgare L. cv. Rum). Die Bodenkultur, 53 (1): 13-18.

Musick, J.T. and D.A. Dusek (1980). Planting date and water deficit on development and irrigated winter wheat. Agron. Journal., 72(1): 45-52.

Noworolnik, K. (2010). Effect of sowing rate on yields and grain quality of new cultivars of spring barley. Polish J. Agronomy., 3: 20-23.

Pessarakli, M. (2001). Handbook of Plant And Crop Physiology. CRC Press, $2^{\text {nd }}$ Edition.

Ramadhan, M.N. (2013). Tillage systems and seeding rates effect on yield components, seed yield and biological yield of barley cultivars. $J$. Basra. Res. Sci., 39 (1A): 33-46.

Randhawa, A.S.; R.S. Jolly and S.S. Dhillon (1977). Response of wheat and barley to nitrogen and different dates of sowing. Crop Improvement, 41 (1): 49-64.

Rashid, A.; R.U. Khan; S.K. Marwat and Z. Ali (2010). Response of barley to sowing date under fertilizer application under rainfed condition. World J. Agric. Sci., 6(5): 480-484.

Razzaque, M.A. and S. Rafiquzzaman (2006). Effect of time of sowing on the yield and yield attributes of barley under rainfed condition. Bangladesh J. Sci. Ind. Res., 41(1-2): 113-118.

Salem, M.A.; M.A. Youssef; L.I. Abdel-Latif and E.F. Hussein (2000). Response of barley (Hordeum vulgare L.) to sowing date, seeding rate and nitrogen fertilization level. Proc. $9^{\text {th }}$ Conf. Agron., Minufiya Univ., Egypt, 183-197.

Samarah, N.H. and T.A. Al-Issa (2006). Effect of planting date on seed yield and quality of barley grown under semi-arid Mediterrnean conditions. J. Food, Agriculture \& Environ., 4 (2): 222-225.

Sharifi, R.S. and Y. Raei (2011). Evaluation of yield and the some of physiological indices of barley (Hordeum vulgare L.) genotypes in relation to different plant population levels. Aust. J. Basic \& Appl. Sci., 5 (9): 578-584.

Snedecor, G.W. and W.G. Cochran (1981). Statistical Methods . $7^{\text {th }}$ Ed., Iowa State University, Press, Ames, Iowa, U.S.A.

Soleymani, A.; M. H. Shahrajabian and L. Naranjani (2011). Determination of the suitable planting density for different cultivars of barley (Hordeum vulgare L.) in Fars. Afr. J. Plant Sci., 5(3): 284-286. 


\title{
استجابة بعض أصناف الشعير لميعاد الزراعة ومعدل التقاوى تحت نظام الرى بالرش في الأراضى الرملية
}

\author{
عبد الرحمن السيد أحمد عمر \\ قسم المحاصيل - كلية الزر اعة المثل ـ جامعة الزقازيق - مصر.
}

أجريت تجربتان حقليتان فى المزر عة التجريبية التابعة لكلية الزر اعـة ـ جامعة

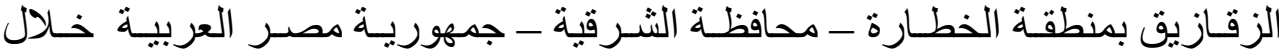

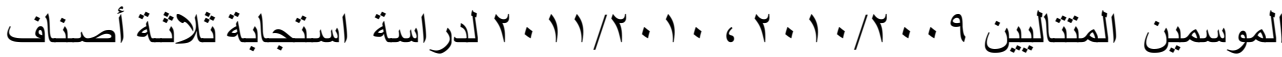

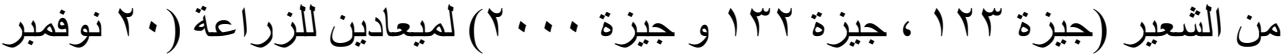

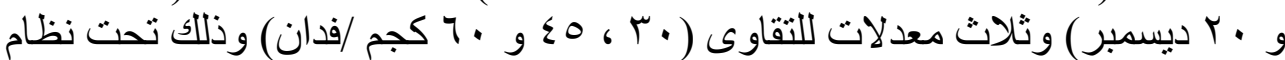

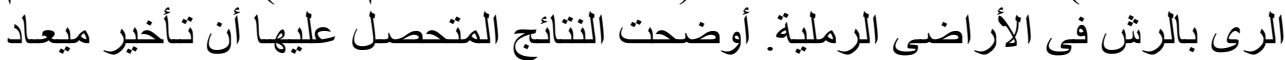

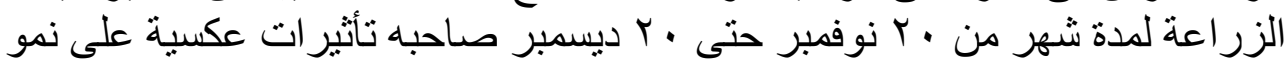

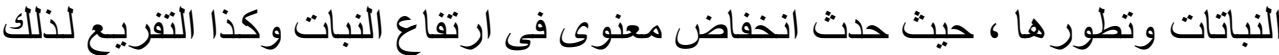

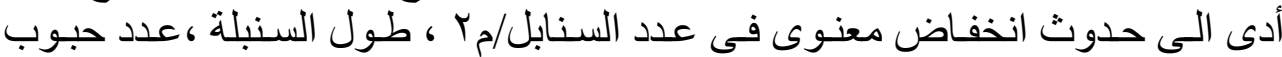

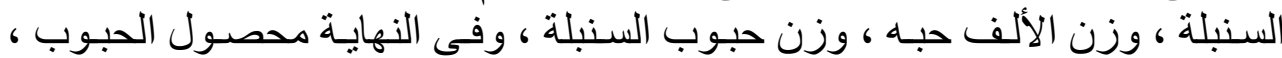

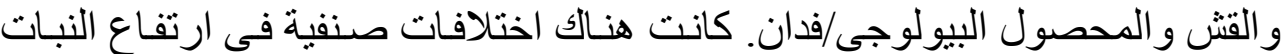

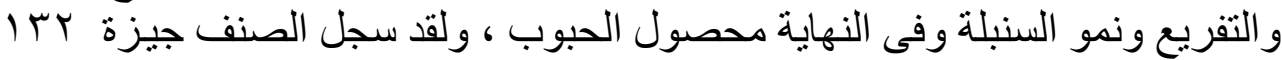

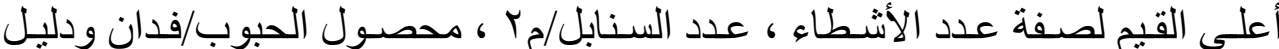

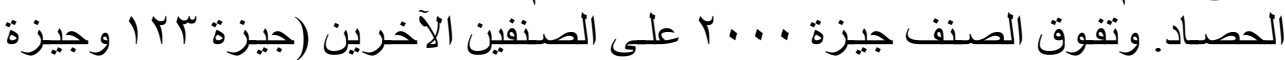

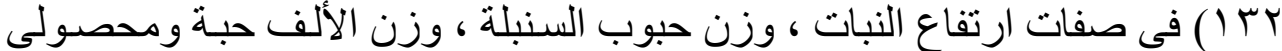


صفات النمو ومساهمات المحصول حيث حدث انخفاض معنوى في طول السنبلة ،

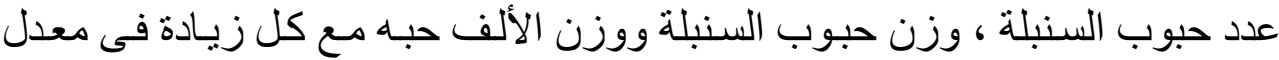

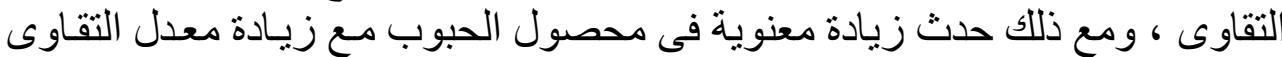

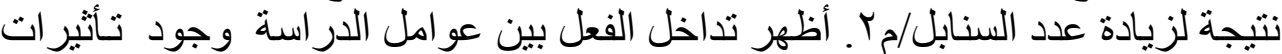

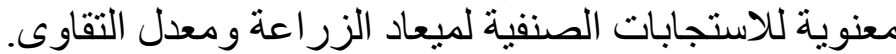

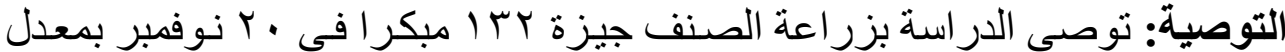

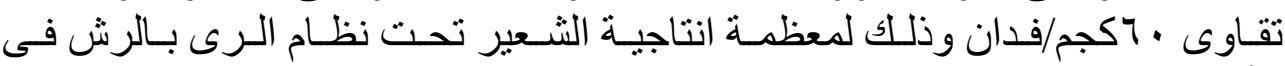

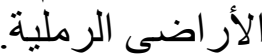

